\title{
Pengembangan Media Pembelajaran Berbasis Trainer (Alat Latih) Perakitan Laptop Di SMK Negeri 2 Makassar
}

\author{
Wahyudin $^{1}$, Hardiansyah ${ }^{2}$ \\ Email: ${ }^{1}$ wahyudin.ptkunm15@gmail.com, ${ }^{2}$ hardiansyaharahman3@gmail.com
}

\begin{abstract}
Abstrak. Penelitian ini bertujuan (1) untuk mengetahui tahapan dan menghasilkan Trainer perakitan laptop sebagai media pembelajaran dasar program keahlian perakitan komputer/laptop SMK Negeri 2 Makassar, (2) Untuk mengetahui tingkat kevalidan, kepraktisan dan keefektifan Trainer (alat latih) Perakitan Laptop sebagai media pembelajaran dasar program keahlian perakitan komputer/laptop di SMKN 2 Makassar, (3) untuk mengetahui aktivitas belajar siswa dalam menggunakan Trainer perakitan laptop sebagai media pembelajaran dasar program keahlian perakitan komputer/laptop di SMKN 2 Makassar, dan (4) untuk mengetahui respon siswa pada penerapan Trainer perakitan laptop sebagai media pembelajaran dasar program keahlian perakitan komputer/laptop SMKN 2 Makassar. Penelitian ini merupakan penelitian pengembangan yang difokuskan untuk mengembangkan media pembelajaran Trainer perakitan laptop. Model pengembangan yang digunakan dalam penelitian ini mengacu pada model pengembangan ADDIE yang dilakukan dengan beberapa tahap yakni analisis, design, development, implementation, dan evaluation. Media pembelajaran Trainer perakitan laptop yang telah dikembangkan, divalidasi oleh dua orang ahli dan mengalami revisi sehingga didapatkan hasil yang sangat layak digunakan. Hasil penelitian menunjukkan bahwa (1) Trainer perakitan laptop sebagai media pembelajaran yang dikembangkan setelah dilakukan validasi media tersebut dinyatakan sangat valid, (2) media pembelajaran Trainer perakitan laptop dikatakan praktis karena seluruh aspek dalam pembelajaran berada pada kategori sangat terlaksana, (3) Trainer perakitan laptop sebagai media pembelajaran dikatakan efektif karena telah memenuhi kriteria keefektifan, dengan hasil: (1) memenuhi syarat kevalidan, (2) aktivitas belajar siswa terlaksana seluruhnya, (3) aktivitas guru terlaksana seluruhnya, dan (4) siswa memberikan respon yang positif terhadap media pembelajaran Trainer perakitan laptop serta (5) nilai hasil belajar siswa yang keseluruhannya yang memperoleh ketuntasan.
\end{abstract}

\section{Kata Kunci:_Media Pembelajaran, Pengembangan, Trainer Perakitan Laptop}

\section{PENDAHULUAN}

Pesatnya perkembangan ilmu pengetahuan dan teknologi akan menciptakan struktur baru, yaitu struktur global. Struktur tersebut mengakibatkan semua bangsa di dunia termasuk Indonesia, mau tidak mau akan terlibat dalam suatu tatanan global yang seragam, pola hubungan dan pergaulan yang seragam khususnya dibidang ilmu pengetahuan dan teknologi. Sumber daya manusia (SDM) merupakan salah satu faktor kunci dalam pembangunan bangsa, yakni bagaimana menciptakan SDM yang berkualitas dan memiliki keterampilan serta berdaya saing tinggi dalam persaingan global.

Sekolah Menengah Kejuruan (SMK) merupakan salah satu lembaga pendidikan yang bertanggungjawab untuk menciptakan sumber daya manusia yang memiliki kemampuan, keterampilan dan keahlian, sehingga lulusannya dapat mengembangkan kinerja apabila terjun dalam dunia kerja. Pendidikan SMK bertujuan meningkatkan kemampuan siswa untuk dapat mengembangkan diri sejalan dengan perkembangan ilmu pengetahuan, teknologi dan kesenian, serta menyiapkan siswa untuk memasuki lapangan kerja dan mengembangkan sikap profesional.

Rendahnya prestasi belajar siswa disebabkan karena: (1) kurangnya motivasi siswa untuk belajar mengikuti proses belajar mengajar di dalam kelas; (2) kurangnya perhatian atau konsentrasi siswa terhadap apa yang disampaikan oleh guru; (3) penyampain materi oleh guru kurang jelas sehingga siswa kurang menangkap materi pelajaran; (4) penulisan kata-kata dan gambar dari guru sebagai visualisasi materi pelajaran kurang jelas; 
(5) peran guru sebagai fasilitator dan moderator bagi terciptanya situasi belajar yang kondusif bagi siswa belum dilaksanakan secara optimal; (6) sebagian besar guru mengajar masih menggunakan metode konvesional dan menulis pada papan tulis yang tidak melibatkan siswa secara aktif; (7) belum adanya model pembelajaran berbasis Trainer/alat latih (Sarana dan Prasarana) yang sesuai untuk dasar keahlian perakitan komputer/laptop, sehingga tujuan kompetesi dasar dan KKM yang telah ditetapkan tidak dapat tercapai.

\section{Dasar Program Keahlian Perakitan Komputer/Laptop}

Dasar Program Keahlian Perakitan komputer (Laptop) adalah salah satu mata pelajaran wajib bidang keahlian Teknologi Informasi dan Komunikasi (TIK) pada program studi keahlian Teknik Komputer dan Informatika (TKI) dengan peminatan Teknik Komputer dan Jaringan (TKJ). Berdasarkan struktur kurikulum SMK kelompok peminatan C2 dasar program keahlian perakitan komputer laptop disampaikan di kelas X semester ganjil dan semester genap.

Trainer (alat latih) perakitan laptop yang dijadikan media pembelajaran, maka dipandang perlu membahas bagian-bagian dari laptop. Pada umumnya Laptop (Notebook) memiliki fungsi yang sama dengan komputer desktop (Dekstop Computer). Komponen yang terdapat di dalamnya sama persis dengan komponen pada desktop, hanya saja ukurannya diperkecil, dijadikan lebih ringan, lebih tidak panas, dan lebih hemat daya listrik. (Widada, 2014).

\section{Trainer (alat latih) Perakitan Laptop}

Trainer berasal dari bahasa Inggris training, yang artinya latihan, dan trainer, yang artinya pelatih atau disini adalah alat latih (Kamus Inggris Indonesia, 1996). Trainer adalah bagian dari training yang bertanggung jawab dalam meningkatkan kualitas pribadi dan kinerja trainer (pengikut latihan) atau disini adalah siswa SMK secara langsung, sehingga tidak heran peran trainer begitu sentral, secara khusus trainer dalam istilah teknik adalah alat latih.

Rencana pengajaran perakitan komputer / laptop dengan menggunakan media pembelajaran Trainer (alat latih) Perakitan Laptop Perakitan komputer adalah salah satu mata pelajaran wajib kompetensi keahlian dalam peminatan Teknik Komputer dan Jaringan (TKJ). Berdasarkan struktur kurikulum pada dasar program keahlian perakitan komputer disampaikan di kelas X semester 1 dan 2 masingmasing 4 jam pelajaran, dengan Kompetensi Inti (KI) dan Kompetensi Dasar (KD) pembelajaran menekankan pada pengenalan perangkatperangkat yang ada pada laptop serta spesifikasinya sampai proses perakitan laptop.

Menurut Oemar Hamalik (2008) terdapat tiga pendekatan yang dilakukan dalam usaha memilih media pembelajara, yaitu (1) dengan cara memilih media telah dipasarkan yang dapat dibeli pendidik dan langsung dapat digunakan dalam proses pengajaran, dan (2) memilih berdasarkan kebutuhan nyata yang telah direncanakan, khususnya yang berkenaan dengan tujuan yang dirumuskan secara khusus dan bahan yang hendak di sampaikan (3) merancang suatu alat pembelajaran.

Berdasarkan uraian di atas, Pengembangan media pembelajaran trainer (alat latih) perakitan laptop merupakan media yang bersifat alat peraga, di mana media tersebut lebih menekankan pentingnya materi dibanding proses pengembangan materi tersebut dan dapat digunakan sebagai sumber media komunikasi. Karakteristik dari media ini peserta didik tidak hanya memperhatikan media atau objek, melainkan dituntut juga untuk berinteraksi selama mengikuti pembelajaran, sehingga pengguna dan media dapat saling melakukan aksi yang dapat menarik perhatian dan kemauan belajar secara sengaja proses belajar terjadi dan aktivitas belajar dapat meningkat.

\section{METODE PENELITIAN}

Medote penelitian dan pengembangan atau disebut Research and Development (R\&D) adalah metode penelitian yang digunakan untuk menghasilkan produk tertentu, dan menguji keefektifan produk tersebut, (Sugiyono, 2016). Untuk menghasilkan suatu media pembelajaran yang diaplikasikan pada dasar program keahlian perakitan komputer/laptop. Model desain pengembangan yang digunakan dalam penelitian ini adalah model Analysis, Desain, Develompment, Implementation dan Evaluation (ADDIE) (Muh. Rohman, 2013). 
Subjek dalam penelitian ini adalah siswa kelas X TKJ 1 dengan jumlah siswa keseluruhan, di ambil secara acak untuk desain uji coba tahap pertama sebanyak 5 orang dan desain uji coba tahap kedua sebanyak 33 orang.

Jenis data digunakan sebagai dasar untuk menentukan keefektifan, dan kepraktisan produk yang dihasilkan. Jenis data yang ada dalam penelitian ini yakni data kuantitatif. Data kuantitatif dihimpun dengan menggunakan angket penilaian secara umum tentang produk Trainer laptop sebagai media pembelajaran perakitan komputer.

Data kuantitatif yang dikumpulkan melalui angket merupakan penilaian siswa dan guru yang meliputi tampilan isi dari media yang dihasilkan untuk mencapai tujuan pemanfaatan dan peningkatan daya tarik media pembelajaran pada peminatan Teknik Komputer dan Jaringan (TKJ) SMK Negeri 2 Makassar, sedangkan data kualitatif dihimpun melalui hasil penelitian, masukan, kritik, tanggapan, dan saran perbaikan yang diperoleh melalui angket, wawancara dan hasil observasi.

Berdasarkan uji coba yang dilakukan, diharapkan mampu mengungkap data yang diinginkan dalam penelitian ini. Data yang ingin diungkap dalam tahap uji coba yakni:

a) Kevalidan Trainer (alat latih).

b) Keefektifan penggunaan trainer (alat latih)

c) Kepraktisan Trainer (alat latih) perakitan laptop sebagai media pembelajaran dasar program keahlian perakitan komputer laptop.

\section{HASIL DAN PEMBAHASAN}

1. Analisis Kebutuhan Peralatan

Peralatan yang dibutuhkan untuk pengembangan Trainer perakitan laptop pada kelas X TKJ 1 peminatan Teknik Komputer dan Jaringan (TKJ) di SMK Negeri 2 Makassar yaitu : (1) Bor listrik, (2) Tang, (3) Cutter, (4) Solder, (5) Obeng Set, (6) Mistar, (7), Klirik / fiber glass dan (8) Rangka Alumnium.

2. Uji coba awal media trainer PC

Uji coba tahap awal pada media Trainer perakitan laptop dimaksudkan untuk mengetahui kekurangan pada media Trainer perakitan laptop sebelum dilakukan uji tahap pengembangan kelompok kecil dan uji tahap pengembangan kelompok besar pada kelas $\mathrm{X}$
TKJ 1 peminatan TKJ SMK Negeri 2 Makassar. Hasil dari uji coba tahap awal tidak ditemukan kekurangan pada media Trainer perakitan laptop karena media Trainer perakitan laptop sudah sesuai dengan pembelajaran perakitan laptop.

3. Tahap Pengembangan pertama (Kelompok kecil)

a. Analysis

Berdasarkan hasil pengamatan menunjukkan ketersediaan peralatan praktikum di laboratorium SMK Negeri 2 Makassar khususnya di LAB TKJ masih terbatas. Hal ini menyebabkan proses belajar mengajar pada dasar program keahlian perakitan komputer/laptop kurang maksimal.

b. Design

Tahap pengembangan media pembelajaran Trainer perakitan laptop pada kompetensi keahlian perakitan komputer/laptop sebagai berikut:

a) Pembelajaran perakitan laptop dibuat media pembelajaran berbentuk Trainer perakitan laptop.

b) Media Pembelajaran yang dibuat ke dalam Trainer perakitan laptop, sebanyak empat pertemuan dalam materi pembelajaran.

c) Untuk memudahkan penggunaan Trainer perakitan laptop, dibuat buku panduan dan buku ajar untuk menjelaskan cara kerja dan hal-hal yang berkaitan dengan laptop pada media Trainer perakitan laptop yang telah dibuat.

Untuk mengetahui kevalidan, efektifitas dan kepraktisan media, dibuat instrumen untuk pengukuranya. Adapun instrumen yang dibuat, diantaranya: (a) instrumen aktivitas belajar siswa, (b) instrumen aktivitas guru, (c) instrumen buku panduan/buku ajar, (d) instrumen keterlaksanaan media, (e) instrumen respon siswa, (f) instrumen ahli media dan, (g) instrumen ahli materi, serta $(\mathrm{h})$ Tes hasil belajar siswa (pre test dan post test).

c. Development 
Tahapan ini menghasilkan media pembelajaran Trainer perakitan laptop pada dasar program keahlian perakitan komputer/laptop yang sudah direvisi berdasarkan masukan dari para pakar/ahli maupun setelah dilakukan uji coba tahapan pengembangan pertama. Adapun langkah-langkah dalam tahapan pengembangan sebagai berikut :

a) Trainer perakitan laptop

Media Trainer perakitan laptop sebagai media pembelajaran perakitan komputer/laptop dibuat menggunakan bahan-bahan sederhana dan mudah didapatkan. Sebelum membuat Trainer perakitan laptop ada beberapa bahan yang perlu disiapkan yaitu: (a) aluminum yang digunakan untuk membuat rangka dari media Trainer perakitan laptop, (b) akrelik/fiber glass digunakan untuk papan tempat sandaran komponen perangkat laptop (transparan). Trainer perakitan laptop menggunakan akrelik/fiber glass karena mempunyai tekstur ringan, kuat dan mudah dibentuk.

b) Komponen perangkat keras

Perangkat keras yang dibutuhkan Trainer perakitan laptop diantaranya :
a. Processor intel celeron dual core @ 1.9 Ghz, b. Motherboard Samsung Sens R430, c. Harddisk 320 GB
b. DVD drive, e. LCD 14"
c. Power supply (Charger)
d. keyboard (Internal \& External), . h. Touchpad
e. Mouse, j. Volt meter (Digital)

c) Buku panduan/Buku Ajar

Buku panduan dan buku ajar dibuat untuk memudahkan siswa dan guru pada saat menggunakan media. Isi dalam bahan ajar, dijelaskan teori dan materi dari perangkat laptop yang digunakan pada media Trainer perakitan laptop.

d) Validasi instrumen

Tahap validasi instrumen dilakukan dengan bekerja sama dengan para ahli untuk melakukan revisi terhadap instrumen yang telah disusun untuk selanjutnya dilakukan pengembangan dan penyempurnaan.

d. Implementation
Hasil perampungan media pada tahap development kemudian di uji coba tahap kelompok kecil. Sebanyak lima siswa yang menjadi subyek uji coba untuk mengetahui respon siswa pada pembelajaran media pembelajaran Trainer perakitan laptop. Terdapat dua kendala siswa terhadap media yang dibangun yaitu, (1) tampilan susunan perangkat keras masih kurang menarik, (2) tampilan pengkabelan pada media Trainer perakitan laptop belum rapi. Selain tanggapan langsung dari siswa mengenai tampilan media, angket respon siswa diberikan untuk diisi. Angket merupakan alat ukur seberapa besar peran media terhadap efektifitas dan kepraktisan dalam proses pembelajaran.

\section{e. Evaluation}

Pada tahap evaluasi pertama, dilakukan dengan melibatkan lima subyek, dimana subyek yang dilibatkan diuji secara terpisah. Data yang terkumpul kemudian dianalisis dengan hasil tujuan awal perancangan ataukah belum menyentuh sedikitpun dari tujuan awal.

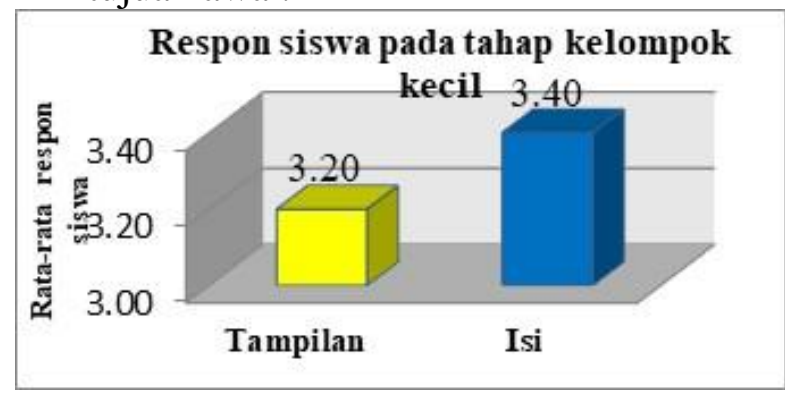

4. Tahap pengembangan kedua

a. Analysis

Berdasarkan hasil respon siswa terhadap media yang dikembangkan pada tahap awal, masih terdapat kekurangan, meski respon telah melampaui rata-rata namun masih terdapat kekurangan dan perlu diadakan revisi.

Aspek yang belum mendapatkan nilai standar adalah pada bagian intrumen isi yaitu Penggunaan Trainer Perakitan Laptop sebagai media pembelajaran dapat membantu saya dalam meningkatkan prestasi belajar lebih baik sebelumnya hanya $60 \%$, Pembelajaran dasar program keahlian Perakitan Komputer dengan menggunakan media Trainer Perakitan 
Laptop yang telah dilaksanakan memberikan saya pemahaman belajar lebih baik daripada pembelajaran lainnya juga kurang yaitu $60 \%$.

\section{b. Design}

Tahap perancangan media pembelajaran Trainer perakitan laptop pada tahap pengembangan kedua berdasarkan tahap kekurangan dan perbaikan pengembangan pertama.

c. Development

Sesuai dengan perencanaan media pada tahapan design. Tahap perbaikan media selanjutnya masih melalui beberapa tahapan. Tahapan dalam hal tampilan tidak mendapatkan respon dengan presentase negatif, artinya dalam hal tampilan Trainer tidak ada masalah.

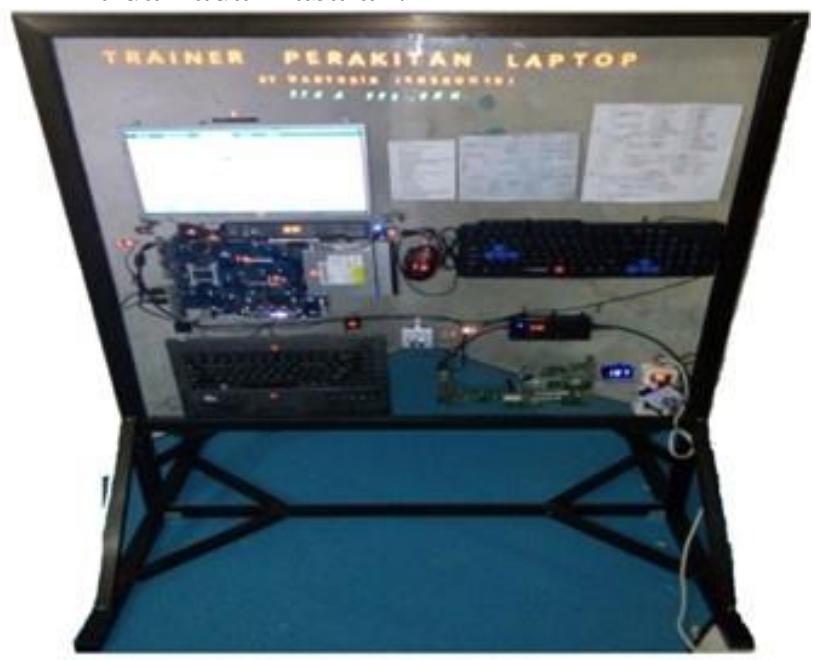

Gambar. pengembangan Tampilan Trainer Perakitan Laptop

d. Implementation

Hasil perampingan media pada pengembangan tahap kelompok besar kemudian diterapkan di kelas. Sebanyak 33 siswa yang menjadi subyek penelitian untuk menguji media Trainer perakitan laptop dan media pendukung yang telah diajarkan. Uji coba pengembangan pada kelompok besar mengambil jumlah subyek 33 orang karena untuk menguji coba media Trainer perakitan laptop yang sudah dikembangkan jadi jumlah subyek lebih banyak dari uji coba tahap pengembangan pertama yaitu di atas 10 orang (Benny A.Pribadi, 2011).
Aktivitas belajar siswa juga diamati pada proses penerapan media yang kedua, begitupun aktivitas guru dan keterlaksanaan media, untuk lebih jelasnya beberapa hal yang menjadi alat tolak ukur keberhasilan atau tidaknya media dalam mendukung tujuan awal proses pembelajaran dapat dilihat pada bagian evaluation.

e. Evaluation

Tahap evaluasi ke dua, dilakukan dengan melibatkan 33 subyek yang dilibatkan diuji secara terpisah antara satu dengan yang lain. Hasil dari pengisian angket merupakan data yang bisa menjawab peran media terhadap tujuan pembelajaran awal. Data dikumpulkan kemudian dianalisis, Hasil analisis dari evaluasi tahap kedua sebagai bahan masukan untuk kembali melakukan revisi produk.

\section{PEMBAHASAN}

Berdasarkan pembahasan RPP media Trainer perakitan laptop dapat disimpulkan bahwa RPP media Trainer perakitan laptop sangat layak digunakan pada pembelajaran dasar program keahlian perakitan komputer/laptop di kelas X TKJ1 peminatan Teknik Komputer dan Jaringan SMK Negeri 2 Makassar.

Berdasarkan penilaian oleh validator ahli pada Buku panduan/buku ajar diperoleh hasil sangat valid terhadap indikator penilaian yang diberikan. Buku panduan/buku ajar media Trainer perakitan laptop membantu proses pembelajaran di kelas X TKJ 1 peminatanTeknik Komputer dan Jaringan SMK Negeri 2 Makassar karena buku panduan media Trainer perakitan laptop dilengkapi pedoman penggunaan media Trainer perakitan laptop.

Instrumen aktivitas belajar siswa diujicobakan, terlebih dahulu dilakukan validasi ahli untuk memberikan penilaian dan koreksi terhadap setiap kriteria aktivitas yang diajukan. Berdasarkan penilaian validator diperoleh hasil analisis yang menunjukkan kevalidan setiap pernyataan yang diberikan.

Sedangkan instrumen respon siswa berdasarkan penilaian diperoleh hasil sangat valid yang menunjukkan bahwa angket respon siswa dapat digunakan untuk mengukur respon siswa sebelum proses pembelajaran perakitan 
komputer/laptop menggunakan media Trainer perakitan laptop dilaksanakan.

Kualitas media pembelajaran Trainer perakitan laptop dilihat dari :

(1) Kevalidan, berdasarkan hasil penilaian dari 2 validator, menunjukkan bahwa keseluruhan komponen instrumen yang dinyatakan sangat valid dengan sedikit revisi. Oleh karena itu dilakukan revisi berdasarkan saran para ahli dan diperoleh hasil revisi yang selanjutnya diujicobakan.

Hasil analisis validasi RPP diperoleh rata-rata 3,70 yang berarti sangat valid, bahan ajar/buku panduan diperoleh rata-rata 3,77 yang berarti sangat valid, instrumen pengamatan aktivitas belajar siswa 3,81 yang berarti sangat valid, instrumen pengamatan aktivitas guru 3,75 yang berarti sangat valid, instrumen keterlaksanaan media 3,72 yang berarti sangat valid, instrumen respon siswa 3,78 yang berarti sangat valid, hasil validasi media 3,66 yang berarti sangat valid dan hasil validasi materi 3,56 yang berarti sangat valid, berdasarkan batas interval $3.5 \leq \mathrm{M}<$ 4.0 (sangat valid).

(2) kepraktisan, berdasarkan penilaian umum terhadap semua komponen yang telah divalidasi oleh ahli pada umumnya semua validator memberikan penilaian dinyatakan sangat valid dan dapat digunakan dengan sedikit revisi. Hasil pengamatan dua orang pengamat terhadap keterlaksanaan media dikatakan memadai karena semua komponen-komponen yang menjadi penilaian dalam instrumen terlaksana seluruhnya dengan tingkat realibilitas yang tinggi, dengan menunjukkan rata-rata $M=3,52$ yang berada pada rentang $3.5 \leq \mathrm{M}<4.0$ yang berarti sangat terlaksana, sehingga media yang dikembangkan memenuhi kriteria kepraktisan.

Berdasarkan pembahasan kepraktisan bahwa pengembangan Trainer perakitan laptop sebagai media pembelajaran dasar program keahlian perakitan komputer/laptop memenuhi kriteria kepraktisan, karena semua komponen yang menjadi penilaian dalam instrumen keterlaksanaan penggunaan media menunjukkan nilai rata-rata $\mathrm{M}=3,52$ yang berarti sangat terlaksana terhadap media pembelajaran Trainer perakitan laptop.

(3) keefektifan terhadap media yang dikembangkan diperoleh berdasarkan dengan kriteria yang telah disebutkan pada bab III.
Tingkat keefektifan media ini dilihat dari lima kriteria yakni berdasarkan hasil validasi ahli, aktivitas siswa, aktivitas guru dan respon siswa serta hasil belajar siswa terhadap media yang dikembangkan.

Hasil analisis data kriteria tersebut sebagai berikut :

a. Validasi ahli

Validasi ahli terhadap keefektifan media yang dikembangkan sebagai berikut: (1) keefektifan produk ditinjau dari aspek kemenarikan media pembelajaran dengan rata-rata 3,83 dengan kategori sangat valid, (2) keefektifan produk ditinjau dari aspek efektifitas dengan rata-rata 3,50 dengan kategori sangat valid. Berdasarkan uraian penilaian ahli dapat disimpulkan bahwa keefektifan media Trainer perakitan laptop yang dikembangkan dapat diterapkan di kelas X TKJ1 peminatan Teknik Komputer dan Jaringan (TKJ) di SMK Negeri 2 Makassar.

b. Aktivitas belajar siswa

Berdasarkan pengamatan yang telah dilakukan seluruh aktivitas belajar siswa terlaksana seluruhnya khususnya aktivitas belajar siswa dalam memperhatikan materi pembelajaran dasar program keahlian perakitan komputer/laptop dengan menggunakan media Trainer perakitan laptop, aktivitas belajar siswa dalam mengajukan pertanyaan dan aktivitas belajar siswa dalam menulis materi pelajaran media Trainer perakitan laptop.

c. Aktivitas guru

Berdasarkan pengamatan yang telah dilakukan semua aktivitas guru terlaksana seluruhnya khususnya aktivitas guru dalam menjelaskan materi menggunakan Trainer perakitan laptop sebagai media pembelajaran, aktivitas guru menilai sikap dan keterampilan siswa dalam melakukan praktek perakitan komputer/laptop dengan media Trainer perakitan laptop dan aktivitas guru dalam menyimpulkan hasil praktek merakit laptop dan mengingatkan pentingnya kecermatan, ketelitian, keuletan dan kejujuran dalam mempresentasekan media Trainer perakitan laptop.

d. Respon siswa 
Penilai pengguna terhadap media Trainer perakitan laptop yang dikembangkan pada uji coba tahap pengembangan kedua adalah sebagai berikut 1) keefektifan produk ditinjau dari aspek tampilan 3,54 dan 2) keefektifan produk ditinjau dari aspek isi 3,58 kedua aspek yang ditanyakan dikatakan mendapat respon positif karena melebihi $70 \%$ dengan kategori sangat baik.

e. Hasil Belajar siswa

Berdasarkan hasil belajar terhadap media Trainer perakitan laptop yang dikembangkan dan proses belajar mengajar dalam beberapa pertemuan menunjukkan hasil yang baik, yang sebelumnya diberikan tes awal (pre test) dengan nilai rata-rata 70,24 dengan 13 orang belum tuntas, sedangkan pada hasil belajar pada pemberian ujian tes akhir (post test) sebanyak 33 orang dengan nilai rata-rata 83,36 dengan keseluruhan tuntas.

\section{KESIMPULAN}

Berdasarkan analisis data yang telah dilakukan dan dapat disimpulkan dari hasil penelitian ini, yaitu tahapan-tahapan proses pengembangan Trainer perakitan laptop sebagai media pembelajaran, pengembangan Trainer perakitan laptop sebagai media pembelajaran ditinjau dari kevalidan, keefektifan, dan kepraktisan, aktivitas belajar siswa dengan menggunakan Trainer perakitan laptop sebagai media pembelajaran dan respon siswa pada penerapan Trainer perakitan laptop sebagai media pembelajaran dalam proses belajar di sekolah sebagai berikut:

1. Proses pengembangan media pembelajaran Trainer perakitan laptop mengacu pada model ADDIE

2. Proses pengembangan media pembelajaran Trainer perakitan laptop yang dihasilkan memenuhi syarat valid, praktis dan efektif. Kevalidan media pembelajaran Trainer perakitan laptop di peroleh dari validasi instrumen yang dilakukan oleh validator ahli dan berada pada kategori sangat valid, kepraktisan diperoleh dari hasil pengamatan instrumen keterlaksanaan media dan berada pada kategori sangat terlaksana, sedangkan keefektifan media pembelajaran Trainer perakitan laptop di peroleh berdasarkan hasil validasi ahli dan dinyatakan memenuhi syarat kevalidan, aktivitas belajar siswa terlaksana seluruhnya dan aktivitas guru terlaksana seluruhnya serta siswa memberikan respon positif terhadap media yang dikembangkan dan diperoleh dari hasil pengamatan dari pengamat menunjukan sangat efektif.

3. Produk media pembelajaran Trainer perakitan laptop yang dihasilkan efektif dan layak untuk digunakan pada pembelajaran dasar program keahlian perakitan komputer/laptop. Hal ini dapat dilihat dari penilaian aktivitas belajar siswa pada penerapan media pembelajaran Trainer perakitan laptop dasar program keahlian perakitan komputer kelas X TKJ1 peminatan Teknik Komputer dan Jaringan (TKJ) SMK Negeri 2 Makassar menghasilkan rata-rata dengan kategori sangat baik.

4. Produk media pembelajaran Trainer perakitan laptop yang dihasilkan efektif dan layak untuk digunakan pada pembelajaran dasar program keahlian perakitan komputer/laptop. Hal ini dapat dilihat dari penilaian respon siswa pada penerapan media pembelajaran Trainer perakitan laptop dasar program keahlian perakitan komputer/laptop kelas X TKJ1 peminatan Teknik Komputer dan Jaringan SMK Negeri 2 Makassar menghasilkan rata-rata dengan kategori sangat baik.

\section{DAFTAR PUSTAKA}

Adi Purwanto, Moh. Khairudin, (2016). Pengembangan Trainer Arduino Untuk Standar Kompetensi Memprogram Sistem Pengendali Elektronik. Jurnal Pendidikan Teknik Elektro UNY Vol.6 No.04

Arief S. Sadiman, dkk. 2011. Media Pendidikan, Pengertian, Pengembangan dan Pemanfaatannya. Jakarta: PT. Raja Grafindo Persada .

Asnawir, Usman MB. 2002. Media pembelajaran.Ciputat: Ciputat Pers

Azhar Arsyad, 2011. Media Pembelajaran. Jakarta : PT. Raja Grafindo Persada.

Azhar Arsyad, 2015. Media Pembelajaran. Jakarta : PT. Raja Grafindo Persada. 
Benny A. Pribadi 2014. Desain dan Pengembangan Program Pelatihan Berbasis Kompetensi: Implementasi Model ADDIE. Jakarta: Prenada Media Group

Benny A. Pribadi, 2010. Model Desain System Pembelajaran. Jakarta: T. Dian Rakyat.

Benny A. Pribadi, 2011. Model ASSURE untuk mendesain pembelajaran sukses. Jakarta: PT. Dian Rakyat.

Darmawan, D. 2012. Inovasi Pendidikan: Pendekatan Praktek Teknologi Multimedia dan Pembelajaran Online. Bandung: Remaja Rosdakarya.

Dewi Salma. 2009. Prinsip Desain Pembelajaran. Jakarta: Prenada Media Group.

Edy Sulistyo, 2014. Pengembangan Media Pembelajaran Trainer Televisi Pada Mata Pelajaran Memperbaiki Sistem Penerima Televisi Program Keahlian Audio Video di SMK N 5 Surabaya. Jurnal Pendidikan Teknik Elektro. Volume 03 Nomor 03

Endang Mulyiatiningsih. 2013. Metode Penelitian Terapan Bidang Pendidikan. Bandung: Alfabeta

Finch Curtis.R\& Crunkilton, J.R. 1999. Curriculum Development in Vocational and Technical Education: Planning, Content, and Implementation. Sidney: Allyn and Bacon.

M. Rodhi Faiz, Dedi Tri Laksono, (2014). Pengembangan Trainer Integrasi Pembangkit Listrik Skala Piko. Jurnal Tekno, Vol : 21

Muh. Rohman, Sofan Amri, 2013. Stategi \& Desain Pengembangan Sistem Pembelajaran. Jakarta: Prestasi Pustakaraya.

Oemar Hamalik, 2008. Kurikulum dan Pembelajaran. Jakarta: Bumi Aksara.

Oemar Hamalik, 2011. Proses Belajar Mengajar. Jakarta: Bumi Aksara

Peraturan Pemerintah Republik Indonesia Nomor 29 Tahun 1990. Tentang Pendidikan Menengah.

Rusman, 2012. Pembelajaran berbasis teknologi informasi dan komunikasi. Jakarta: Rajawali Press.
Saifuddin Azwar, 2007. Reliabilitas dan Validitas. Yogyakarta: Pustaka Pelajar

Saifuddin Azwar, 2013. Fungsi dan Pengembangan Pengukuran Prestasi Belajar. Yogyakarta: Pustaka Pelajar.

Sardiman, 2010. Interaksi Motivasi Belajar Mengajar. Jakarta: Rajawali

Schippers, Uwe \& Patriana, Djadjang Madya. 1994. Pendidikan Kejuruan di Indonesia. Bandung: Angkasa.

Siswati. 2013. Modul Perakitan Komputer untuk SMK/MAK Kelas $X . \quad$ Malang: Kementerian Pendidikan \& Kebudayaan PPPPTK BOE Malang

Slamet PH, Pengembangan SMK Model untuk masa depan, FT Universitas Negeri Yogyakarta.Cakrawala Pendidikan, Februari 2013, Th. XXXII.

Sudjana, dkk. 2011. Teknologi Pengajaran. Bandung: Sinar Baru

Sugiyono. 2016. Metode Penelitian Pendidikan, Pendekatan Kuatitatif, Kualitatif dan $R \& D$. Bandung: Alfabeta.

Suharsimi Arikunto, 2013. Manajemen Penelitian. Jakarta: PT Rineka Cipta.

Sukirman, D dan Asra. 2011. Kurikulum dan Pembelajaran (Tim Pengembang MKDP Kurikulum dan Pembelajaran). Jakarta: Rajawali Pers.

Wardiman Djoyonegoro. 1997. Pengembangan Sumber daya Manusi a Melalui Sekolah Menengah Kejuruan. Jakarta: PT. Jayakarta Agung.

Widada, 2014. Kitab Teknisi Komputer Laptop Printer dan Monitor. Yogyakarta: Mediakom

Wina Sanjaya, 2012. Media Komunikasi Pembelajaran. Jakarta: Prenada Media Group. 